\author{
ROMAN ULIASZ \\ ORCID: 0000-0002-3143-1941 \\ Uniwersytet Rzeszowski
}

\title{
O MIEJSCU PRAWA SPÓŁEK W SYSTEMIE PRAWA
}

\begin{abstract}
Abstrakt: Intencją autora niniejszego artykułu jest próba określenia relacji prawa spółek względem zarówno prawa cywilnego, jak i prawa handlowego. W artykule przedstawiono argumenty mające przemawiać za tym, że prawo spółek jest $\mathrm{w}$ istocie bardziej wyodrębnionym zespołem norm prawnych, niż mogłoby to wynikać z tradycyjnego postrzegania tego prawa jako jednego z komponentów prawa handlowego, a przez to i prawa cywilnego. Ma za tym przemawiać przede wszystkim to, że na gruncie prawa spółek klasycznym instytucjom i pojęciom prawa cywilnego nadaje się znacząco odmienną treść.
\end{abstract}

Słowa kluczowe: spółki, prawo cywilne, prawo handlowe, odrębność

Gdyby poddać analizie poszczególne ustawodawstwa z punktu widzenia istniejącej na ich gruncie relacji między prawem cywilnym a prawem handlowym, to przynajmniej „na pierwszy rzut oka” okazałoby się, że można tu zidentyfikować dwa niezależne podejścia: podejście monistyczne, oparte na koncepcji jedności prawa cywilnego (prywatnego), i podejście dualistyczne, zakładające rozdzielność (autonomiczność) obu gałęzi prawa. Wśród ustawodawstw państw realizujących koncepcję monistyczną wymienia się Szwajcarię, Włochy, Holandię, Polskę, a niekiedy także kraje anglosaskie, natomiast w Niemczech, Francji i Belgii przeważa koncepcja dualistyczna ${ }^{1}$.

Taka ścisła klasyfikacja porządków prawnych wydaje się jednak pewnym uproszczeniem, choćby $\mathrm{z}$ tego powodu, że w ramach każdej z tych grup usta-

1 A. Całus, Miejsce instytucji prawa handlowego w procesie komercjalizacji prawa cywilnego. Uwagi w zwiazku z pracami nad nowym kodeksem cywilnym, [w:] Instytucje prawa handlowego w przysztym kodeksie cywilnym, red. T. Mróz, M. Stec, Warszawa 2012, s. 30; J. Okolski, D. Opalska, [w:] Prawo handlowe, red. J. Okolski, M. Modrzejewska, Warszawa 2016, s. 37; J. Frąckowiak, Ustawodawstwo dotyczące przedsiębiorców pod rządami zasady jedności prawa cywilnego, „Przegląd Prawa Handlowego” 2000, nr 11, s. 1. 
wodawstw można dostrzec sporą niejednolitość, gdy chodzi o sposób określenia relacji między prawem cywilnym a prawem handlowym (w tym prawem spółek). Jeżeli przyjrzymy się systemom prawnym tradycyjnie kwalifikowanym jako te, w których realizuje się koncepcję monistyczną, to okaże się, że w przypadku Włoch i Szwajcarii prawo handlowe, w tym prawo spółek, zostało uregulowane w jednym akcie prawnym (kodeksie cywilnym), podczas gdy na przykład w Polsce regulacja spółkowa jest - przynajmniej od strony formalnej — regulacją odrębną (z tym jednak zastrzeżeniem, że materialnie rzecz ujmując, prawo spółek stanowi część prawa cywilnego, w szczególności za sprawą stosowania na gruncie prawa spółek przepisów kodeksu cywilnego wprost, a dopiero w dalszej kolejności odpowiednio).

Również w innych systemach, w których realizuje się koncepcję monistyczną, mamy do czynienia z zachowaniem, przynajmniej od strony normatywnej, znacznej odrębności prawa spółek. Tak jest na przykład w Argentynie, gdzie od 1 sierpnia 2015 roku obowiązuje kodeks cywilny i handlowy z 2014 roku (Código Civil y Comercial de la Nación), jednak regulacja ta nie obejmuje prawa spółek, które pozostaje uregulowane w ustawie o spółkach handlowych z 1984 roku (Ley de sociedades comerciales). Podobnie jest w Rumunii — tu z dniem 1 października 2011 roku doszło do „wcielenia” dotychczas obowiązującego kodeksu handlowego do nowego kodeksu cywilnego (Codul civil) i w ten sposób, jak to wprost się podkreśla w literaturze, dokonano odejścia od systemu dualistycznego na rzecz systemu monistycznego ${ }^{2}$. Mimo to poza regulacją tego aktu prawnego pozostawiono dużą część prawa spółek (rumuński kodeks cywilny obejmuje w zasadzie tylko ogólną regulację dotyczącą spółek, zawartą w art. 1.881 n. rumuńskiego kodeksu cywilnego).

Z tymi ustawodawstwami trudno skojarzyć, także kwalifikowane jako monistyczne, systemy prawne oparte na wzorcu anglosaskim, które z pewnymi wyjątkami nie tyle realizują koncepcję monistyczną, ile opierają się na znacznym partykularyzmie regulacyjnym, nie tylko na linii ,prawo cywilne — prawo handlowe”, lecz także w ramach samego tradycyjnie pojętego prawa cywilnego. Zarówno w ustawodawstwie obowiązującym w Wielkiej Brytanii, jak i Stanach Zjednoczonych prawo spółek stanowi zawsze przedmiot osobnej regulacji prawnej, przy czym sprowadza się ona niekiedy do tego, że — jak w Wielkiej Brytanii — mamy odrębną regulację dotyczącą poszczególnych spółek osobowych (partnerships) ${ }^{3}$ oraz niezależną regulację dotyczącą spółek kapitałowych (companies $)^{4}$. Natomiast

2 Zob. E. Veress, The new Romanian Civil Code - difficulties in the transition towards a monist private law, [w:] New Civil Codes in Hungary and Romania, red. A. Menyhárd, E. Veress, „Ius Gentium: Comparative Perspectives on Law and Justice" 63, Basel 2017, s. 27 n.

3 Spółkom osobowym poświęcona jest ustawa o spółkach osobowych z 1890 roku (Partnership Act) oraz ustawa o spółkach komandytowych z 2000 roku (Limited Liability Partnerships Act).

${ }^{4}$ Mowa tu o ustawie o spółkach kapitałowych z 2006 roku (Companies Act). Tekst tej ustawy dostępny jest na stronie http://www.legislation.gov.uk/ (dostęp: 25.03.2020). Ustawa o spół- 
relacji prawa spółek (czy też relacji aktów prawnych dotyczących poszczególnych spółek) do prawa cywilnego nie da się po prostu określić, choćby z tego powodu, że samo prawo cywilne pozostaje gałęzią nieskodyfikowaną w ramach jednego aktu prawnego $i$ jest $w$ istocie zbiorem samodzielnych regulacji prawnych dotyczących poszczególnych dziedzin prawa cywilnego (osobna regulacja prawa zobowiązań, spadków itp.).

Również odnośnie do krajów, w których realizuje się model dualistyczny, nie można w ramach tej grupy ustawodawstw nie dostrzec znacznego zróżnicowania, gdy chodzi o sposób określenia relacji między prawem cywilnym a handlowym. Przykładowo, w ustawodawstwie niemieckim na płaszczyźnie normatywnej mamy rozdzielność między prawem cywilnym ${ }^{5}$ a prawem handlowym ${ }^{6}$, jednak istotną cechą tego ustawodawstwa jest nieskodyfikowanie prawa spółek w ramach jednego aktu prawnego. Otóż większość niemieckich spółek osobowych została objęta regulacją kodeksu handlowego z 1897 roku, przy czym spółka cywilna (Gesellschaft bürgerlichen Rechts) podlega regulacji w niemieckim kodeksie cywilnym z 1896 roku, spółka partnerska (Partnerschaftsgesellschaft) zaś została uregulowana w odrębnej ustawie o spółce partnerskiej z 1994 roku (Partnerschaftsgesel1schaftsgesetz). Także spółki kapitałowe pozostają przedmiotem regulacji dwóch odrębnych aktów prawnych, a mianowicie ustawy o spółkach z ograniczoną odpowiedzialnością z 1892 roku $^{7}$ oraz ustawy o spółce akcyjnej z $1965 \mathrm{roku}^{8}$. Zupełnie inaczej jest w ustawodawstwie francuskim, również tradycyjnie kwalifikowanym do systemów prawnych realizujących koncepcję dualistyczną. Na gruncie prawa francuskiego, podobnie jak w prawie niemieckim, istnieje wprawdzie osobna regulacja stricte cywilistyczna ${ }^{9}$ oraz odrębna regulacja stosunków handlowych w postaci kodeksu handlowego ${ }^{10}$, jednakże ten ostatni akt prawny, w przeciwieństwie do niemieckiego kodeksu handlowego, obejmuje większość regulacji spół-

kach kapitałowych z 2006 roku jest dość rozbudowaną regulacją prawną i zasadniczo można jej przypisać cechę kompleksowości, przynajmniej jeżeli chodzi o spółki kapitałowe (choć i tu można wskazać wyjątki, zob. np. Company Directors Disqualification Act z 1986 roku). Więcej o systematyce angielskiego prawa spółek kapitałowych zob. B. Hannigan, Company Law, Oxford 2016, s. 8-16; M. Cordes et al., Shackleton on the Law and Practice of Meetings, London 2006, s. 109 n.; English Private Law, red. A. Burrows, Oxford 2007, s. 170 n.; A. Ridley, Ch. Shepherd, Company Law, London-New York 2015, s. 1-3; Ch. Villiers, Sustainable companies: Barriers and possibilities in UK company law, „International and Comparative Corporate Law Journal” 2015, nr 1, s. $108 \mathrm{n}$.

${ }^{5}$ Zob. niemiecki kodeks cywilny z 1896 roku (Bürgerliches Gesetzbuch).

${ }^{6}$ Zob. niemiecki kodeks handlowy z 1897 roku (Handelsgesetzbuch).

${ }^{7}$ Gesetz betreffend die Gesellschaften mit beschränkter Haftung (GmbHG). Począwszy od 2008 roku, we wskazanym akcie prawnym (między innymi w § 5a GmbHG) poddano regulacji też uproszczoną spółkę z o.o. (Unternehmergesellschaft).

8 Aktiengesetz.

${ }^{9}$ Zob. francuski kodeks cywilny (Code civil), www.legifrance.gouv.fr.

${ }^{10}$ Zob. francuski kodeks handlowy z 1807 roku (Code de commerce), www.legifrance.gouv.fr. 
kowej ${ }^{11}$. W systemie prawa francuskiego prawo spółek, odmiennie niż w prawie niemieckim, przybiera zatem postać zespołu norm skodyfikowanych w zasadzie w ramach jednego aktu prawnego ${ }^{12}$. Z kolei bardziej na wzorcu niemieckim oparte zostało ustawodawstwo hiszpańskie, w którym kodeks handlowy ${ }^{13}$ jest regulacją odrębną od kodeksu cywilnego ${ }^{14}$, jednak nie obejmuje całości prawa spółek, w szczególności zaś obszernej regulacji dotyczącej spółek kapitałowych ${ }^{15}$.

Z tych uwag wynika, że zarówno w systemach uznawanych za monistyczne (na przykład w Wielkiej Brytanii), jak i w systemach dualistycznych (w Niemczech bądź Hiszpanii) prawo spółek bywa objęte niezależną od kodeksu cywilnego regulacją prawną, przy czym regulacja spółkowa może być zamieszczona w kilku różnych aktach prawnych. Natomiast bardzo ścisłe powiązanie formalne (normatywne) prawa spółek z ogółem prawa cywilnego jest widoczne przede wszystkim na gruncie ustawodawstwa włoskiego i szwajcarskiego. Gdyby zatem postawić pytanie o miejsce prawa spółek w systemie prawnym poszczególnych ustawodawstw, okazałoby się, że odpowiedź na nie pozostawałaby bez związku z tym, czy dane ustawodawstwo zaliczamy do systemów realizujących koncepcję monistyczną, czy dualistyczną.

Niezależnie od tego, że zarówno systemy monistyczne, jak i dualistyczne mogą zawierać odrębną regulację prawa spółek (to znaczy ani monizm, ani dualizm prawa prywatnego nie jest determinantem odrębności normatywnej prawa spółek), można dokonać obserwacji, że zgodnie z tradycyjnym podejściem, obecnym chyba na gruncie wszystkich ustawodawstw kontynentalnych, prawo spółek stanowi w istocie część prawa handlowego i to niezależnie od tego, czy prawo handlowe wykazuje bliższą (modele monistyczne) czy dalszą (modele dualistyczne) relację z prawem cywilnym bądź całością prawa prywatnego. To podejście przejawiało się, i niekiedy nadal się przejawia, w nazewnictwie aktów prawnych: podobnie jak polski kodeks handlowy z 1934 roku był w istocie w znacznej części kodeksem spółek handlowych (skoro obejmował regulację nie tylko czynności handlowych, lecz także spółek handlowych), tak w wielu współczesnych aktach

11 Francuski kodeks handlowy z 1807 roku obejmuje postanowienia dotyczące zarówno spółek kwalifikowanych w Polsce jako spółki osobowej (na przykład société en nom collectif), jak i tych, które uznajemy za spółki kapitałowe (na przykład société à responsabilité limitée).

12 Jednym z wyjątków jest zawarta w art. $1845 \mathrm{n}$. francuskiego kodeksu cywilnego regulacja dotycząca spółki cywilnej (société civile).

13 Zob. hiszpański kodeks handlowy z 1885 roku (Código de Comercio), www.boe.es.

14 Zob. hiszpański kodeks cywilny z 1889 roku (Código Civil), www.boe.es.

15 Zob. ustawa o spółkach kapitałowych z 2010 roku (Ley de Sociedades de Capital), www. boe.es. 
prawnych określanych jako „kodeks handlowy” przedmiotem regulacji jest i prawo czynności handlowych, i prawo spółek ${ }^{16}$. Ten sam wniosek można wysnuć, jeżeli przyjrzeć się zawartości tematycznej polskich bądź zagranicznych podręczników do prawa handlowego. W kwestii prawa kontynentalnego nikt więc właściwie nie kwestionuje, że prawo handlowe to między innymi prawo spółek.

Odmienne podejście przeważa w porządkach prawnych, które tradycyjnie kwalifikuje się jako systemy common law. Prawo handlowe w krajach anglosaskich (commercial law) to po prostu ,prawo handlu” (prawo obrotu handlowego), co odpowiada przede wszystkim unormowaniom dotyczącym umowy sprzedaży lub dostawy (to jest umów w obrocie towarowym), umów o pośrednictwo handlowe, a niekiedy także regulacjom dotyczącym finansowania transakcji handlowych czy sposobu ich zabezpieczenia bądź ubezpieczenia ${ }^{17}$. W żadnym razie w zakresie przedmiotowym prawa handlowego nie mieści się natomiast prawo spółek (company law, the law of partnerships), któremu poświęca się osobne podręczniki i które wykłada się jako osobny przedmiot dydaktyczny. Powstaje w tym momencie pytanie, czy doświadczenia krajów anglosaskich i przyjęte tam rozwiązania prawne można wykorzystać w dyskusji na temat odrębności prawa handlowego i prawa cywilnego, w szczególności zaś w rozważaniach na temat odrębności samego prawa spółek. Nie chodzi tu bynajmniej o szczegółową analizę poszczególnych porządków prawnych systemu common law i ich odnoszenie do prawa polskiego, ale o odpowiedź na pytanie, czy podejście zakładające znaczną odrębność prawa spółek czy w ogóle prawa korporacyjnego od prawa cywilnego (a więc podejście właściwie oparte na założeniu, że prawo spółek to osobna gałąź prawa) może być uzasadnione także na gruncie polskiego systemu prawnego. Nie chodzi tu też o to, by dewaluować obecnie obowiązujący art. 2 k.s.h. Warto natomiast odpowiedzieć na pytanie, czy można znaleźć argumenty przemawiające za twierdzeniem, że prawo spółek bądź prawo korporacyjne może być (a może zasługuje na to, aby być) potraktowane jako osobna od prawa cywilnego gałąź prawa.

Wiele przemawia za tym, że prawo spółek wykazuje znaczną specyfikę, jeżeli je zestawić z innymi działami prawa handlowego. Gdyby — tak jak w systemach common law - uznać prawo handlowe za „prawo obrotu handlowego”, a zatem zespół norm regulujących czynności handlowe, a prawo spółek za zespół norm regulujących powstanie, organizację, funkcjonowanie (zarówno na płaszczyźnie

16 Zob. przede wszystkim art. L210 n. francuskiego kodeksu handlowego z 1807 roku (Code de commerce), a także art. $200 \mathrm{n}$. kodeksu handlowego Republiki Wenezueli z 1955 roku (Código de Comercio) oraz art. 98 n. kolumbijskiego kodeksu handlowego z 1971 roku (Código de Comercio).

17 Zob. np. E. Baskind, G. Osborne, L. Roach, Commercial Law, Oxford 2019; R. Bradgate, Commercial Law, Oxford 2000; Goode on Commercial Law, red. E. McKendrick, London 2010. 
wewnętrznej, jak i zewnętrznej) oraz ustanie spółki jako osoby prawnej lub ułomnej osoby prawnej, to nietrudno dostrzec, że między tymi komponentami tradycyjnie pojętego prawa handlowego istnieje znaczna różnica. Tak ujęte prawo spółek $\mathrm{w}$ istocie nie ma nic wspólnego z obrotem jako takim (dokonywaniem czynności handlowych), pomijając to, że spółka jako podmiot prawa w takim obrocie uczestniczy. Sposób uczestniczenia spółek w obrocie (sposób zawierania, modyfikacji, rozwiązywania oraz zabezpieczania umów handlowych), wyłączając regulacje dotyczące reprezentacji spółek, nie jest jednak przedmiotem regulacji spółkowych, ale przynależy do materii prawa umów. Natomiast prawo spółek to normy regulujące sposób zorganizowania określonego podmiotu prawa, sposób współdziałania poszczególnych osób uczestniczących w tym podmiocie czy wreszcie sposób występowania tego podmiotu w relacji do osób trzecich. Co oczywiste, materia prawa spółek jest o wiele bogatsza, jednak niezależnie od tego, który zespół norm przynależnych do prawa spółek weźmiemy pod uwagę, okaże się, że normy te regulują materię tak dalece wyspecjalizowaną i odrębną od obrotu handlowego, że teza o potrzebie wyodrębnienia prawa spółek jako osobnej gałęzi prawa stanie się jeszcze bardziej uzasadniona. Wystarczy tu wskazać regulacje dotyczące operacji na kapitale zakładowym (podwyższenie i obniżenie kapitału zakładowego) czy pozakodeksowe regulacje mające za przedmiot funkcjonowanie rynku instrumentów finansowych.

Nakreślona natura prawa spółek jako zespołu norm regulujących wewnętrzną strukturę i funkcjonowanie określonego podmiotu prawa na płaszczyźnie wewnętrznej i zewnętrznej znajduje odzwierciedlenie w rodzajach sporów sądowych, jakie wynikają na gruncie tej gałęzi prawa. Powszechnie przyjmuje się, że przepis kodeksu spółek handlowych z 2000 roku, który bywa najczęściej wykorzystywany w sporach sądowych z zakresu prawa spółek, to art. 299 k.s.h. Nawet jeżeli tak jest, to sama częstotliwość przywoływania tego przepisu nie może świadczyć o naturze sporów korporacyjnych, które są o wiele bardziej zróżnicowane i rzadko kiedy przypominają ,klasyczne” spory z zakresu prawa obrotu handlowego ${ }^{18}$. O ile bowiem art. 299 k.s.h. jest podstawą prawną sporów między wierzycielami spółek z o.o. a zarządcami tych spółek o zapłatę (i tu można doszukać się podobieństwa do innych sporów z zakresu obrotu handlowego), to już w przypadku innych sporów korporacyjnych takie podobieństwo jest znikome. Dla przykładu można zapytać, co wspólnego z obrotem handlowym ma spór powstały wsku-

18 Por. w związku z tym propozycję A. Radwana, Reforma polskiego prawa spółek „w działaniu” - o potrzebie utworzenia wyspecjalizowanych sądów korporacyjnych, „Allerhand Working Paper" 2018, nr 24, s. 30-32. 
tek zaskarżenia przez jednego ze wspólników powództwem o uchylenie uchwały zgromadzenia wspólników o ustaleniu wynagrodzenia członka zarządu albo spór powstały wskutek wniesienia przez jednego ze wspólników do sądu rejestrowego wniosku o zobowiązanie zarządu do udzielenia wyjaśnień lub udostępnienia dokumentów bądź ksiąg spółki (art. $212 \S 4$ k.s.h.) czy wreszcie spór zainicjowany przez wniesienie przez wspólnika reprezentującego co najmniej jedną dziesiątą kapitału zakładowego, także do sądu rejestrowego, wniosku o wyznaczenie firmy audytorskiej w celu zbadania rachunkowości oraz działalności spółki (art. 223 k.s.h.)? Zarówno spór wynikły z zaskarżenia uchwały zgromadzenia wspólników, jak i spory toczone przed sądem rejestrowym są niekiedy ważnym elementem rozgrywki między wspólnikami mniejszościowymi a tymi, którzy dysponują większością kapitałową, i to może one przede wszystkim powinny zostać uwzględnione przy określaniu natury sporów generowanych na gruncie prawa spółek.

Jak nietrudno zauważyć, kodeks spółek handlowych niejednokrotnie posługuje się pojęciami znanymi i powszechnie używanymi w „klasycznym” prawie cywilnym (na przykład reprezentacja, pełnomocnictwo, nieważność). Choć na gruncie prawa spółek występuje wiele instytucji prawa cywilnego, to jednak gdy przyjrzeć się bliżej kształtowi im nadanemu przy okazji odnoszenia ich do stosunków korporacyjnych, wówczas widać, że częstokroć odbiega on od kształtu, jaki instytucje te mają w swojej pierwotnej, podstawowej wersji. Nie zawsze chodzi tu o to, jaki kształt w prawie spółek zostaje nadany tym cywilnoprawnym instytucjom przez ustawodawcę, ale o to, że zastosowanie tych instytucji do stosunków korporacyjnych niejako wymusza istotne zmiany w sposobie pojmowania i definiowania tych instytucji, skądinąd „tradycyjnie” cywilistycznych.

Chyba najbardziej jaskrawym przykładem takiej modyfikacji klasycznej instytucji cywilnoprawnej w prawie spółek jest kształt, jaki nadaje się sankcji nieważności uchwały zgromadzenia spółki kapitałowej. Nie jest to miejsce, aby udzielać odpowiedzi na pytanie, czy sankcja, o której mowa w art. $252 \S 1$ i art. $425 \S 1$ k.s.h., jest tą samą co sankcja nieważności określona w art. 58 § 1 k.c., czy może jest $\mathrm{w}$ istocie sankcją wzruszalności (uchylalności), czy też jest to trzeci, nieznany na gruncie kodeksu cywilnego, rodzaj sankcji ${ }^{19}$. Znaczące jest natomiast, że powołanie się na nieważność uchwały zostało wyraźnie ograniczone zarówno podmiotowo, jak i temporalnie. Nie budzi w zasadzie wątpliwości, że w przeciwieństwie do sytuacji, w której żąda się stwierdzenia nieważności czynności prawnej, o czym mowa w art. $58 \S 1$ k.s.h., dopuszczalność wniesienia powództwa o stwierdzenie

19 Por. R. Uliasz, Nieważność uchwały zgromadzenia spótki kapitałowej, Warszawa 2018, s. $252-259$. 
nieważności uchwały zgromadzenia spółki kapitałowej została ograniczona prawie wyłącznie do osób wymienionych w art. 250 k.s.h. i art. $422 \S 2$ k.s.h. Dopuszczalność wniesienia takiego powództwa podlega też limitom czasowym, co oznacza, że po upływie określonych przez ustawodawcę terminów powództwo winno zostać oddalone ${ }^{20} \mathrm{i}$ tym samym nie zostanie osiągnięty zamierzony przez powoda skutek w postaci stwierdzenia nieważności uchwały. Mimo że ustawodawca na gruncie kodeksu spółek handlowych mówi o nieważności uchwały, to nie sposób nie spostrzec, że sankcja ta — niezależnie od zastosowanej nomenklatury — ma w istocie inny kształt niż sankcja nieważności z art. 58 § 1 k.c.

Także to, w jaki sposób sankcję nieważności uchwały postrzega się w orzecznictwie, może być argumentem przemawiającym za tym, że na gruncie stosunków korporacyjnych „klasyczne” instytucje cywilnoprawne przybierają zupełnie odmienny kształt. Jak pokazała praktyka stosowania prawa, sankcja nieważności uchwały zgromadzenia spółki kapitałowej, nawet przy uwzględnieniu wprost przewidzianych przez ustawodawcę ograniczeń o charakterze podmiotowym i czasowym, jest sankcją zbyt dolegliwą, jest bowiem ona konsekwencją — lege non distinguente — każdej sprzeczności uchwały z ustawą. $Z$ tego też względu w orzecznictwie przyjęto, że jeżeli chodzi o sprzeczność z ustawą trybu zwołania zgromadzenia i trybu podjęcia uchwały (uchybienia proceduralne), to mogą one prowadzić do nieważności uchwały wyłącznie wtedy, gdy mają charakter istotny, to znaczy mogły one mieć wpływ na treść uchwały ${ }^{21}$. Podobne konsekwencje, w kwestii znacznego zmodyfikowania kształtu sankcji nieważności, ma linia orzecznicza, w której świetle wyrok stwierdzający nieważność uchwały zgromadzenia spółki kapitałowej ma charakter konstytutywny ${ }^{22}$. Taka reakcja judykatury na sankcję nieważności uchwały zgromadzenia,

20 Ibidem, s. 554.

21 Zob. wyrok SN z dnia 8 grudnia 1998 roku, I CKN 243/98, Legalis; wyrok SN z dnia 10 marca 2005 roku, III CK 477/04, Legalis; wyrok SN z dnia 16 marca 2005 roku, III CK 477/04, Legalis; wyrok SN z dnia 5 lipca 2007 roku, II CSK 163/07, Legalis; wyrok SN z dnia 19 września 2007 roku, II CSK 165/07, Legalis; wyrok SN z dnia 28 listopada 2007 roku, V CSK 285/07, Legalis; wyrok SN z dnia 26 marca 2009 roku, I CSK 253/08, Legalis; wyrok SN z dnia 24 czerwca 2009 roku, I CSK 510/08, Legalis; wyrok SA w Poznaniu z dnia 23 lutego 2010 roku, I ACa 86/10, Legalis; wyrok SN z dnia 9 września 2010 roku, I CSK 530/09, Legalis; wyrok SN z dnia 12 października 2012 roku, IV CSK 186/1, Legalis; wyrok SA w Katowicach z dnia 24 października 2012 roku, V ACa 417/12, Legalis. Odmiennie wyrok SA w Poznaniu z dnia 6 listopada 2007 roku, I ACa 884/07, LEX nr 370701.

22 Zob. przede wszystkim uchwałę SN (7) z dnia 1 marca 2007 roku, III CZP 94/06, Legalis; uchwałę SN (7) z dnia 18 września 2013 roku, III CZP 13/13, Legalis. Wyrazem wskazanej linii orzeczniczej były też orzeczenia i uchwały: wyrok SN z dnia 13 lutego 2004 roku, II CK 438/02, Legalis; uchwała SN z dnia 17 lutego 2004 roku, III CZP 116/03, Legalis; wyrok SN z dnia 16 marca 2006 roku, III CSK 32/06, Legalis; wyrok SN z dnia 4 grudnia 2009 roku, III CSK 85/09, Legalis; wyrok SN z dnia 24 lutego 2011 roku, III CSK 150/10, Legalis; wyrok SN z dnia 13 maja 2011 roku, V CSK 361/10, Legalis; uzasadnienie uchwały SN z dnia 20 grudnia 2012 roku, III CZP 84/12, OSNC 2013, nr 7-8, poz. 83; wyrok SA w Warszawie z dnia 6 marca 2013 roku, I ACa 1218/09, Legalis; wyrok SN z dnia 23 września 2014 roku, II UK 560/13, OSNAPiUS 2016, nr 2, poz. 25. 
choć niejednokrotnie krytykowana w części, w której uznaje ona konstytutywny charakter wyroku stwierdzającego nieważność uchwały, jest jednak zrozumiała, wyraża bowiem potrzebę złagodzenia sankcji nieważności bezwzględnej, co z kolei bardziej odpowiada potrzebom obrotu.

Autonomiczność prawa spółek względem regulacji cywilistycznych można również zaobserwować w przypadku pełnomocnictwa do głosowania na zgromadzeniu spółki kapitałowej (art. 243 i art. $412-412^{2}$ k.s.h.). Należy tu nadmienić, że pełnomocnictwo to bywa niekiedy kwalifikowane inaczej niż pełnomocnictwo, o którym mowa w art. 98 n. k.c. ${ }^{23}$

Za odrębnością prawa spółek od prawa cywilnego przemawia też sposób kwalifikowania uchwał podejmowanych przede wszystkim przez zgromadzenia spółek kapitałowych, choć trzeba zaznaczyć, że pytanie o naturę prawną uchwał można odnieść również do uchwał podejmowanych przez wspólników spółek osobowych. Wprawdzie większość przedstawicieli doktryny postrzega uchwały jako czynności prawne ${ }^{24}$, to jednak nie sposób nie dostrzec takich cech w uchwałach, dzięki którym akty te mogłyby być traktowane odmiennie, to jest jako czynności konwencjonalne niestanowiące czynności prawnych ${ }^{25}$. Za przyjęciem stanowiska, że uchwała tworzy samodzielną kategorię zdarzenia prawnego, niezależną od kategorii czynności prawnych, przemawia wiele argumentów. Przede wszystkim tryb kształtowania się woli zbiorowej, która zostaje następnie wyrażona $\mathrm{w}$ formie uchwały, znacząco odbiega od sposobu wyrażania woli w przypadku dokonywania „klasycznych” czynności prawnych. Proces dochodzenia przez osoby uczestniczące w głosowaniu do wspólnego stanowiska, które zmaterializuje się następnie jako uchwała, różni się od trybu wyrażania woli przez podmioty dokonujące jednostronnych, dwustronnych lub wielostronnych czynności prawnych (na przykład umów spółek). Nie to jest jednak najistotniejsze. Główne znaczenie ma bowiem

23 Na przykład w wyroku SA w Warszawie z dnia 21 czerwca 2000 roku, I ACa 189/00, OSA 2001, nr 7, poz. 41, przyjęto, że pełnomocnictwo do głosowania jest pełnomocnictwem do czynności organizacyjnych (faktycznych), a nie prawnych, nie jest to zatem pełnomocnictwo, o którym mowa w art. 98 n. k.c. W konsekwencji nie znajduje do niego zastosowania na przykład instytucja potwierdzenia. Różnic między pełnomocnictwem uregulowanym w k.c. a pełnomocnictwem, o którym mowa w k.s.h., dopatruje się też K. Oplustil, Petnomocnictwo do występowania na walnym zgromadzeniu akcjonariuszy spółki publicznej po nowelizacji kodeksu spótek handlowych ustawa z 5.12.2008 r., „Przegląd Prawa Handlowego” 2009, nr 11, s. 4.

${ }^{24}$ E. Marszałkowska-Krześ, Charakter prawny uchwaty, „Przegląd Prawa Handlowego” 1998, nr 6, s. 26; A. Wolter, J. Ignatowicz, K. Stefaniuk, Prawo cywilne - zarys części ogólnej, Warszawa 2001, s. 263; Z. Radwański, [w:] System Prawa Cywilnego, t. 2. Prawo cywilne - część ogólna, red. Z. Radwański, Warszawa 2008, s. 183; S. Łazarewicz, Charakter prawny uchwat, [w:] Instytucje prawa handlowego..., s. 761 n.; R. Żebrowski, Charakter prawny uchwat zgromadzeń spótek kapitałowych, „Krytyka Prawa” 6, 2014, s. 426-428; S. Sołtysiński, Przepisy ogólne kodeksu spótek handlowych (wybrane zagadnienia), „Państwo i Prawo” 2001, nr 7, s. 7-8.

25 Zob. J. Frąckowiak, Uchwaty zgromadzeń wspólników spótek kapitałowych sprzeczne z ustawa, „Przegląd Prawa Handlowego” 2007, nr 11, s. 6; idem, Charakter prawny uchwał organów spótek kapitałowych a ich zaskarżalność, „Przegląd Prawa Handlowego” 2014, nr 9, s. 29. 
to, że uchwała jest w założeniu rezultatem przyjęcia pewnej fikcji prawnej, że dana zbiorowość opowiedziała się za jej podjęciem. Tymczasem niejednokrotnie jedynie niektórzy uczestnicy głosowania będą podmiotami popierającymi uchwałę, natomiast pozostali będą zainteresowani tym, aby poddana pod głosowanie uchwała nie została podjęta. Mając to na względzie, można powiedzieć, że istota uchwały polega na sztucznym przypisaniu określonej woli danej zbiorowości. Wolę, która znalazła odzwierciedlenie w treści uchwały, faktycznie reprezentują bowiem ci, którzy oddali swój głos za uchwałą, natomiast pozostali uczestnicy głosowania mogą być wyrazicielami intencji przeciwstawnych do tych, które zostały wyrażone głosami osób opowiadających się za uchwałą. Co ważne, wola wyrażona w uchwale nie zostaje przypisana wyłącznie osobom uczestniczącym w głosowaniu, lecz także tym, którzy nie byli obecni na danym zgromadzeniu.

Pozwala to przyjąć, że uchwała znacząco odbiega od pozostałych czynności prawnych, co do których określona wola zostaje przypisana wyłącznie osobom uczestniczącym w dokonywaniu danej czynności prawnej, niezależnie od tego, czy jest to jednostronna czynność prawna, czy też dwu- lub wielostronna. Obojętnie czy mamy do czynienia z udzieleniem pełnomocnictwa, czy z umową spółki — dokonanie czynności prawnej jest wynikiem wyrażenia woli przez wszystkie podmioty dokonujące danej czynności (to jest w przypadku pełnomocnictwa przez mocodawcę, umowy spółki zaś przez osoby zawiązujące spółkę), przy czym treść dokonanej czynności prawnej wiernie oddaje wolę podmiotów dokonujących danej czynności. Nie mamy tu do czynienia z fikcyjnym przypisaniem woli osobom, które takiej woli nie wyraziły. Odmiennie dzieje się w wypadku uchwał - tu przyjmuje się istnienie pozoru woli wspólnej, podczas gdy w rzeczywistości może to być nawet wola wspólnika dysponującego mniejszością kapitałową, przy założeniu, że do podjęcia uchwały doszło pod nieobecność pozostałych wspólników, a w danej spółce nie obowiązywał wymóg kworum ${ }^{26}$.

Konstrukcja uchwały jako czynności z reguły wielostronnej, a nie tylko dwustronnej, jak też zasada, że podjęcie uchwały zwykle nie wymaga zgodnego oświadczenia woli wszystkich podmiotów tę uchwałę podejmujących, rodzi swoiste konsekwencje, gdy jeden ze wspólników uchyla się od swojego oświadczenia woli (głosu) z powołaniem się na którąś z wad oświadczenia woli bądź też głos taki — z powodu wady oświadczenia woli — jest nieważny. Odnośnie do uchwały nie może bowiem budzić wątpliwości, że taka wadliwość pojedynczego głosu nie musi przekładać się na wadliwość całej uchwały i nie musi prowadzić do jej prawnego unicestwienia ${ }^{27}$. Jest to sytuacja odmienna niż ta, która wystąpiłaby, gdyby na wadę oświadczenia woli powołała się jedna ze stron umowy. W tym ostatnim przypadku, jeśli nie ma zgodnego oświadczenia woli obu stron, umowa nie jest zawarta, a w kwestii uchwały -

26 Tak R. Uliasz, op. cit., s. 85-86.

27 Więcej zob. ibidem, s. 375 n. 
mimo że jeden ze wspólników powołałby się na wadę oświadczenia woli — uchwała sama w sobie mogłaby nie być wadliwa i mogłaby wywoływać skutki prawne.

Wszystkie te uwagi dotyczące uchwał podejmowanych przez wspólników pokazują, że podstawowym pojęciom cywilnoprawnym, do których niewątpliwie należy pojęcie czynności prawnych, nadaje się znacząco odmienny kształt niż przypisany pierwowzorowi. Tym bardziej gdy uznamy, zgodnie z dominującym stanowiskiem, że uchwały są czynnościami prawnymi, różnica między tak kwalifikowanymi uchwałami a pozostałymi czynnościami prawnymi będzie szczególnie widoczna.

Podobnego spostrzeżenia można dokonać odnośnie do niektórych zasad „klasycznego" prawa cywilnego, a zwłaszcza zasady swobody umów, której normatywnym wyrazem jest art. $353^{1}$ k.c. W świetle tego przepisu strony zawierające umowę mogą ułożyć stosunek prawny według swego uznania, byleby jego treść lub cel nie sprzeciwiały się właściwości (naturze) stosunku, ustawie ani zasadom współżycia społecznego. Jeżeli rozważymy umowy zawierane na gruncie prawa spółek, zwłaszcza zaś umowy organizacyjne, to okaże się, że zasada owa jest tu bardziej podatna na odstępstwa, a zakres swobody stron zawierających umowę spółki relatywnie węższy niż zakres swobody stron zawierających inną umowę. Przykładowo, w prawie spółek jest wiele przepisów, które pozwalają osobom zawierającym umowę (statut) spółki handlowej swobodnie ukształtować stosunek prawny wyłącznie „w jedną stronę”, na przykład umowa spółki z o.o. może ustanowić wyłącznie surowsze warunki podejmowania uchwał w sprawie zmiany umowy spółki, rozwiązania spółki lub zbycia przedsiębiorstwa albo jego zorganizowanej części, a także uchwały dotyczącej istotnej zmiany przedmiotu działalności spółki (art. $246 \S 1$ zdanie 3 k.s.h.). Co więcej, jednym z przejawów zasady swobody umów jest dopuszczalność zawierania przez podmioty prawa cywilnego umów niepasujących do żadnego normatywnego wzorca (umów nienazwanych), podczas gdy w przypadku umów organizacyjnych spółek możliwe jest zawieranie tylko takich umów, które określony ustawowo wzorzec realizują, i jedynie w ramach tego wzorca można sobie pozwolić na pewien, relatywnie niski, zakres swobody.

Jak z tego wynika, podstawowa zasada prawa cywilnego doznaje na gruncie prawa spółek znaczących modyfikacji, co z kolei może wzmacniać twierdzenie o kategorialnej odrębności prawa spółek. O specyfice prawa spółek decyduje także — co jest szczególnie widoczne w przypadku spółek kapitałowych — powiązanie między kapitałem reprezentowanym przez danego wspólnika a wpływem, jaki może on wywierać na kształt stosunku prawnego łączącego wszystkich wspólników. Mianowicie większy wpływ na kształt stosunku prawnego łączącego wszystkich wspólników spółki mają ci wspólnicy, którzy dysponują większością kapitałową, mniejszy zaś wpływ może być wywierany przez wspólników mniejszościowych. Przykładowo, żądać wyłączenia wspólnika mogą wyłącznie wspólnicy, których udziały stanowią więcej niż połowę kapitału zakładowego (art. 266 $\S 1$ k.s.h.). 
Przedstawione argumenty w opinii autora niniejszego artykułu mogą być głosem w dyskusji o potrzebie wyodrębnienia prawa spółek od innych komponentów, z których składa się prawo handlowe, w szczególności zaś od prawa umów handlowych. Między oboma wymienionymi działami prawa handlowego niewątpliwie istnieje znaczna różnica o charakterze jakościowym. Przedmiot regulacji jest odmienny: podczas gdy prawo obrotu handlowego to przede wszystkim prawo umów, prawo spółek w istocie jest zespołem norm o charakterze organizacyjnym, który przynależy bardziej do prawa korporacyjnego (corporate law) niż prawa cywilnego. Samo określenie ,prawo korporacyjne” jest niezbyt chętnie używane przez przedstawicieli doktryny i kojarzy się raczej z nazwą wyspecjalizowanego działu w dużej kancelarii prawnej. Tymczasem wydaje się, że takie nazewnictwo dość dobrze oddaje naturę prawa spółek i zaznacza jego odrębność w relacji do prawa obrotu handlowego.

Tym bardziej dostrzegalna jest odrębność, gdy zestawi się obok siebie prawo spółek i „klasyczne” prawo cywilne. Można tu zaobserwować, że podstawowe instytucje i pojęcia cywilnoprawne na gruncie prawa spółek uzyskują nową treść dostosowaną do stosunków korporacyjnych. Nie sposób chociażby nie zauważyć istotnych różnic między czynnością prawną a uchwałą, jak i między nieważnością z art. 58 k.c. i nieważnością, o której mowa w art. $252 \S 1$ i art. $425 \S 1$ k.s.h. Wydaje się, że tak wyeksponowane różnice pozwalają na większe wyodrębnienie prawa spółek nie tylko w relacji do ogółu prawa cywilnego, lecz także w relacji do prawa obrotu handlowego. Taka odrębność, którą ma na względzie autor artykułu, realizowana jest przede wszystkim w prawie angielskim. Naturalną konsekwencją takiej odrębności jest wyodrębnienie prawa spółek jako samodzielnego przedmiotu wykładowego, co zresztą ma miejsce w większości krajów opartych na systemie common law.

\section{THE PLACE OF COMPANY LAW IN THE SYSTEM OF LAW}

\section{Summary}

The author has the intention of determining the relations between company law and civil or commercial law. Arguments are presented that company law is in fact a much more separate set of rules than might be implied from the traditional approach, according to which, company law is a component of commercial law and consequently civil law. The reason for this is that under company law "classical" institutions and concepts of civil law have significantly different contents.

Keywords: companies, civil law, commercial law, autonomy 


\section{BIBLIOGRAFIA}

Baskind E., Osborne G., Roach L., Commercial Law, Oxford 2019.

Bradgate R., Commercial Law, Oxford 2000.

Całus A., Miejsce instytucji prawa handlowego w procesie komercjalizacji prawa cywilnego. Uwagi w zwiazku z pracami nad nowym kodeksem cywilnym, [w:] Instytucje prawa handlowego w przyszłym kodeksie cywilnym, red. T. Mróz, M. Stec, Warszawa 2012.

Cordes M., Pugh-Smith J., Keene A.R., Burton J., Caulfield G., Waghorn R., Shackleton on the Law and Practice of Meetings, London 2006.

English Private Law, red. A. Burrows, Oxford 2007.

Frąckowiak J., Charakter prawny uchwat organów spótek kapitałowych a ich zaskarżalność, „Przegląd Prawa Handlowego" 2014, nr 9.

Frąckowiak J., Uchwały zgromadzeń wspólników spółek kapitałowych sprzeczne z ustawa, „Przegląd Prawa Handlowego" 2007, nr 11.

Frąckowiak J., Ustawodawstwo dotyczące przedsiębiorców pod rządami zasady jedności prawa cywilnego, „Przegląd Prawa Handlowego” 2000, nr 11.

Goode on Commercial Law, red. E. McKendrick, London 2010.

Hannigan B., Company Law, Oxford 2016.

Łazarewicz S., Charakter prawny uchwat organów spótek kapitatowych na tle projektu księgi pierwszej kodeksu cywilnego, [w:] Instytucje prawa handlowego w przysztym kodeksie cywilnym, red. T. Mróz, M. Stec, Warszawa 2012.

Marszałkowska-Krześ E., Charakter prawny uchwały, „Przegląd Prawa Handlowego” 1998, nr 6.

Okolski J., Opalska D., [w:] Prawo handlowe, red. J. Okolski, M. Modrzejewska, Warszawa 2016.

Oplustil K., Petnomocnictwo do występowania na walnym zgromadzeniu akcjonariuszy spółki publicznej po nowelizacji kodeksu spótek handlowych ustawa z 5.12.2008 r., „Przegląd Prawa Handlowego" 2009, nr 11.

Radwan A., Reforma polskiego prawa spótek ,w działaniu” - o potrzebie utworzenia wyspecjalizowanych sądów korporacyjnych, „Allerhand Working Paper” 2018, nr 24.

Radwański Z., [w:] System Prawa Cywilnego, t. 2. Prawo cywilne - część ogólna, red. Z. Radwański, Warszawa 2008

Ridley A., Shepherd Ch., Company Law, London-New York 2015.

Sołtysiński S., Przepisy ogólne kodeksu spólek handlowych (wybrane zagadnienia), „Państwo i Prawo" 2001, $\mathrm{nr} 7$.

Uliasz R., Nieważność uchwały zgromadzenia spótki kapitałowej, Warszawa 2018.

Veress E., The new Romanian Civil Code - difficulties in the transition towards a monist private law, [w:] New Civil Codes in Hungary and Romania, red. A. Menyhárd, E. Veress, „Ius Gentium: Comparative Perspectives on Law and Justice" 63, Basel 2017.

Villiers Ch., Sustainable companies: Barriers and possibilities in UK company law, „International and Comparative Corporate Law Journal" 2015, nr 1.

Wolter A., Ignatowicz J., Stefaniuk K., Prawo cywilne - zarys części ogólnej, Warszawa 2001.

Żebrowski R., Charakter prawny uchwat zgromadzeń spótek kapitałowych, „Krytyka Prawa” 6, 2014. 